\title{
Implementasi Arduino Uno dan ATmega328P Untuk Perancangan Alat Keamanan Sepeda Motor
}

\author{
Bakhtiar Rifai $^{1}$, Andi Rosano ${ }^{2}$, Sukmo Aji $^{3}$ \\ ${ }^{1}$ Teknik Informatika, STMIK Nusa Mandiri \\ Jln. Damai No.8 Warung Jati Barat, Jakarta Selatan. \\ ${ }^{23}$ Fakultas Teknologi Informasi, Universitas Bina Sarana Informatika \\ Jl. Kamal Raya No. 18 Ring road Barat, Cengkareng, Jakarta Barat \\ bakhtiar.bri@nusamandiri.ac.id ${ }^{1}$ andi.aox@bsi.ac.id²aji.pls0785@gmail.com ${ }^{3}$
}

\begin{abstract}
Currently in Indonesia the number of motorcycles continues to increase significantly each year. On the other hand the crime rate of motor vehicle theft also increased. This study aims to design a motorcycle security device that can be controlled through android smartphone to reduce the theft of motor vehicles. This tool is mounted on a motorcycle and uses a Bluetooth HC-05 module connection to connect with android smartphone with a maximum distance of +15 meters. The security system used is to disconnect the motorcycle contacts, in addition to functioning as a security tool also serves to locate the existence of a motorcycle while in the parking area by utilizing the horn and motorcycle sein lights. In the application of this security tool can be installed on all brands and types of motorcycles. With the addition of safety equipment on the motorcycle is expected to reduce the theft of motor vehicles are rampant.
\end{abstract}

Abstrak - Saat ini di Indonesia jumlah sepeda motor terus mengalami peningkatan yang signifikan setiap tahunnya. Disisi lain tingkat kejahatan pencurian kendaraan bermotor (curanmor) juga mengalami peningkatan. Penelitian ini bertujuan untuk merancang sebuah alat keamanan sepeda motor yang dapat dikendalikan melalui smartphone android untuk mengurangi tingkat pencurian kendaraan bermotor (curanmor). Alat ini dipasang pada sepeda motor dan menggunakan koneksi modul bluetooth $\mathrm{HC}-05$ untuk terhubung dengan smartphone android dengan jarak maksimal + 15 meter. Sistem keamanan yang digunakan adalah dengan memutus kontak sepeda motor, selain berfungsi sebagai alat keamanan juga berfungsi untuk mencari letak keberadaan sepeda motor saat berada di area parkir dengan memanfaatkan klakson dan lampu sein sepeda motor. Dalam pengaplikasiannya alat keamanan ini dapat dipasang pada semua merk dan tipe sepeda motor. Dengan adanya tambahan alat keamanan pada sepeda motor diharapkan dapat mengurangi tingkat pencurian kendaraan bermotor yang sedang merajalela Keywords - perancangan alat, keamanan sepeda motor, android..

\section{Pendahuluan}

Berdasarkan Badan Pusat Statistik, tercatat dari tahun 2007 jumlah sepeda motor di Indonesia sebanyak 41.955.128 dan pada tahun 2013 jumlah sepeda motor meningkat menjadi 84.732.652, dalam kurun waktu 7 tahun jumlah sepeda motor mengalami kenaikan sebesar $\pm 100 \%$ [1]. Hal itu disebabkan karena sepeda motor merupakan sarana transportasi yang murah dan terjangkau, dan banyaknya dealer dan lembaga pembiayaan yang memberikan kemudahan kredit kepemilikan sepeda motor.

Di Jakarta misalnya, setiap harinya pasti terjadi kemacetan apalagi di jam-jam sibuk, karena itulah masyarakatnya lebih memilih menggunakan sepeda motor karena dinilai lebih cepat sampai ke tempat tujuan di bandingkan dengan mobil dan kendaraan umum lainnya. Dewasa ini kendaraan sepeda motor sudah seperti kebutuhan pokok bagi masyarakat, terutama bagi mereka yang tinggal di kota-kota besar.
Total kejahatan yang terjadi selama tahun 2016 meningkat dari 43.149 pada 2015 menjadi 44.304 pada 2016[2]. Peningkatannya lebih kurang tiga persen, dengan kasus pencurian kendaraan bermotor (curanmor) dengan 2.866 kasus. Jika terus dibiarkan ada kemungkinan di tahun 2017 juga bisa mengalami peningkatan.

Dalam beberapa tahun terakhir, mikrokontroler sangat banyak digunakan terutama dalam pengontrolan robot. Arduino Uno sebagai platform dari Physical computing bersifat open source [3], Arduino IDE (Integrated Development Environment) berguna untuk membuat dan mengedit source code arduino dengan istilah "sketch"[4]. Sketch merupakan source code yang berisi logika dan algoritma yang akan di upload kedalam IC ATmega328P Seiring perkembangan elektronika, mikrokontroler dibuat semakin kompak dengan bahasa pemrograman yang juga ikut berubah. Salah satunya adalah mikrokontroler ATmega328P yang menggunakan teknologi RISC (Reduce Intruction Set Computing) dimana program berjalan lebih cepat karena hanya membutuhkan 
satu siklus clock untuk mengeksekusi satu intruksi program[5]. Mikrokontroler ATmega328P dilengkapi dengan ADC internal, EEPROM internal, Timer/Counter, PWM, analog comparator, dan lain-lain. Sehingga dengan fasilitas yang lengkap ini memungkinkan menggunakan mikrokontroler ATmega328P dengan lebih mudah dan efesien, serta dapat mengembangkan kreativitas penggunaan mikrokontroler ATmega328P.

Pada saat ini smartphone android sudah seperti kebutuhan pokok dikalangan masyarakat luas karena memiliki banyak fungsi dan manfaat. Harga yang terjangkau adalah salah satu alasan masyarakat untuk memiliki berbagai jenis smartphone android dengan beberapa Koneksi diantaranya Bluetooth atau HC-05. Menggunakan modulasi bluetooth V2.0 + EDR (Enchanced Data Rate) 3 Mbps dengan memanfaatkan gelombang radio berfrekuensi 2,4 GHz. Modul ini dapat digunakan sebagai slave maupun master. HC-05 memiliki 2 mode konfigurasi, yaitu AT mode dan Communication mode[6]. AT mode berfungsi untuk melakukan pengaturan konfigurasi dari HC-05. Sedangkan Communication mode berfungsi untuk melakukan komunikasi bluetooth dengan piranti lain.

Berdasarkan permasalahan diatas maka penulis membuat Perancangan Alat Keamanan Sepeda Motor Menggunakan Kendali Android untuk menambah keamanan sepeda motor dan mengurangi tingkat pencurian terhadap kendaraan bermotor. Alat tersebut adalah sebuah alat keamanan yang dibuat dengan menggunakan ATmega328P sebagai mikrokontrolernya yang kemudian dihubungkan dengan kunci kontak sepeda motor dan untuk dapat mempermudah pengendaliannya maka digunakan smartphone android.

Maksud dari penelitian ini dibuat adalah Bagaimana penerapan Alat Keamanan Sepeda Motor Menggunakan Kendali Android dapat bekerja dengan baik dan efektif?

\section{Metode Penelitian}

Metode penelitian yang digunakan ialah ekperimen yaitu penelitian yang berdasarkan atas percobaan penerapan sistem dan implemetasi suatu alat untuk mendapatkan hasil yang baik dalam penelitian ini. Adapaun tahapantahapan penelitian ini iaya

Pada tahapan metode penelitian dilakukan beberapa cara ialah

1. Analisa kebutuhan

Didalam analisa permasalahan penelitian ini membuat merancang kebutuhan yang digunakan untuk implementasi keamanan sistem kendaran bermotor

2. Desain

Desain penelitian ini meliputi membuat blok Rangkaian Alat, Skema Rangakaian alat yang kana dibuat dan prosedur keraalat yang diciptakan

3. Implementasi

Setelah sistem telah di rancang didesain dan ditesting selanjutnya diimpelentasikan pada rancang alat yang akan digunakan untuk penelitian

4. Pengujian Alat

Data yang diperoleh melalui metode ini didapat dengan melakukan pengujian pada alat yang dilakukan berulangkali sehingga memperoleh kinerja alat sesuai dengan yang diinginkan.

Perancangan Alat Keamanan Sepeda Motor Menggunakan Kendali Android ini adalah sebuah alat bantu keamanan yang dipasang pada sepeda motor dengan tujuan untuk mencegah atau mengurangi tingkat pencurian sepeda motor yang semakin merajalela. Alat ini memanfaatkan aki sepeda motor sebagai sumber tegangannya dan juga memanfaatkan buzzer atau klakson dan juga lampu sein sepeda motor sebagai alarm untuk mencari sepeda motor di area parkir.

Alat ini menggunakan ATmega328P sebagai mikrokontrolernya dan dapat dikendalikan melalui smartphone android dengan menggunakan koneksi Bluetooth. Untuk komunikasi antara smartphone android dengan mikrokontroler digunakan modul Bluetooth HC-05. Tidak hanya itu alat ini juga dilengkapi dengan pengukur tegangan aki sepeda motor. Dan sebagai alat monitor status dan kondisi aki maka kita pasang LCD 16x2 agar mudah dalam melihat statusnya.

Alat ini memiliki beberapa fungsi utama yaitu:

1. Mencari lokasi sepeda motor di area parkir melalui smartphone android.

2. Menyalakan kontak sepeda motor melalui smartphone android.

3. Mematikan kontak sepeda motor melalui smartphone android.

4. Memantau kondisi aki dengan LCD 16x2.

Alat keamanan sepeda motor dengan kendali android ini memiliki keterbatasan jarak dalam komunikasi antara smartphone android dan mikrokontroler, dalam komunikasi hanya bisa terkoneksi dengan kendaraan kita dalam radius maximal sekitar 15 meter, tergantung spesifikasi handphone android yang digunakan.

\section{Hasil Penelitian}

Cara penggunaan alat ini cukup mudah, pengguna hanya perlu mengunduh aplikasi Arduino RC di playstore dan menginstalnya. Setelah selesai instalasi aplikasi pada smartphone android kemudian kita nyalakan dahulu bluetooth di smartphone android. Kemudian pengguna harus mengkoneksikan smartphone android dengan Bluetooth modul yang telah tertanam dalam board alat keamanan sepeda motor dengan kendali 
android. Sambungkan bluetooth handphone android dengan bluetooth "SMART SPEEDO. Kemudian pengguna akan diminta password "8511". Setelah berhasil pengguna harus membuka aplikasi Arduino RC dan masuk ke terminal mode di Arduino RC, maka pengguna diminta memasukan kode untuk terhubung dengan kendaraan yang telah tertanam alat keamanan sepeda motor dengan android.

a. Masukan angka " 1 " pada terminal mode maka klakson sepeda motor anda akan berbunyi cepat selama dua kali dan juga lampu sein berkedip, fungsi ini digunakan bila pengguna ingin mencari kendaraan (radius maximal 15 meter).

b. Nyalakan sepeda motor kemudian masukan angka " 2 " pada terminal mode untuk menyalakan kontak sepeda motor atau dengan kata lain sepeda motor siap digunakan, LCD akan menampilkan status Ready to use sepeda motor.

c. Masukan angka " 0 " pada terminal mode makan sistim keamanan sepeda motor akan aktif sehingga sepeda motor akan mati, LCD akan menampilkan status Can't be use sepeda motor.

d. Ketika rangkaian aktif LCD 16x2 akan terus menampilkan voltage aki, sebagai acuan pengguna terhadap kondisi aki kendaraan.

\section{A. Blok Rangkaian Alat}

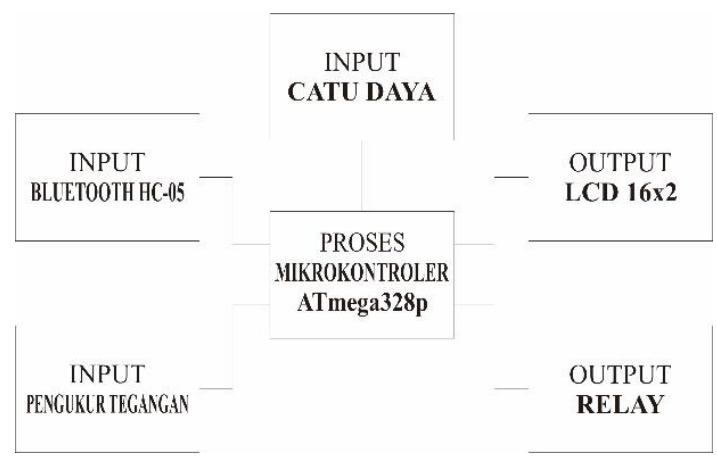

Gbr 1. Blok Diagram Alat

Penjelasan blok diagram alat sebagai berikut:

1) Input

Komponen input ini merupakan komponen masukan yang akan diproses. Komponen input ini terdiri dari :

a. Catu Daya merupakan masukan tegangan dari aki sepeda motor sebesar 12-14 Volt kedalam rangkaian.

b. Bluetooth HC-05 berfungsi sebagai penghubung antara mikrokontroler dengan handphone android.

c. Pengukur tegangan ini berfungsi sebagai pengukur status tegangan aki/baterai sepeda motor.
2) Proses

Proses merupakan komponen utama yang berfungsi sebagai pengelola data yang diterima dari masukan yang kemudian akan menghasilkan output. Dalam proses ini penulis menggunakan mikrokontroler ATmega328P.

3) Output

Output merupakan keluaran dari semua proses yang telah dijalankan. Output yang dihasilkan yaitu :

a. LCD 16x2 berfungsi sebagai monitor untuk melihat status tegangan aki/baterai dan juga status kontak apakan "ON" atau "OFF".

b. Relay berfungsi sebagai saklar yang menghubungkan aki sepeda motor dan klakson dan juga lampu sein sepeda motor.

\section{B. Skema Rangkaian Alat}

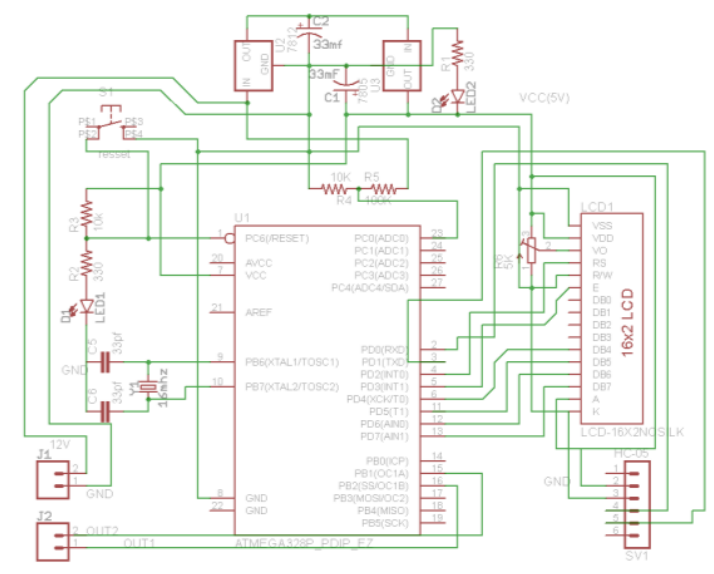

Gbr. 2 Skema Rangkaian

Rangkaian diatas adalah rangkaian keseluruhan dari Alat Keamanan Sepeda Motor Menggunakan Kendali Android ini terdiri dari:

1. Rangkaian Catu Daya.

2. Rangkaian Bluetooth HC-05.

3. Rangkaian Pengukur Tegangan.

4. Rangkaian LCD 16x2.

5. Rangkaian output (Relay). 


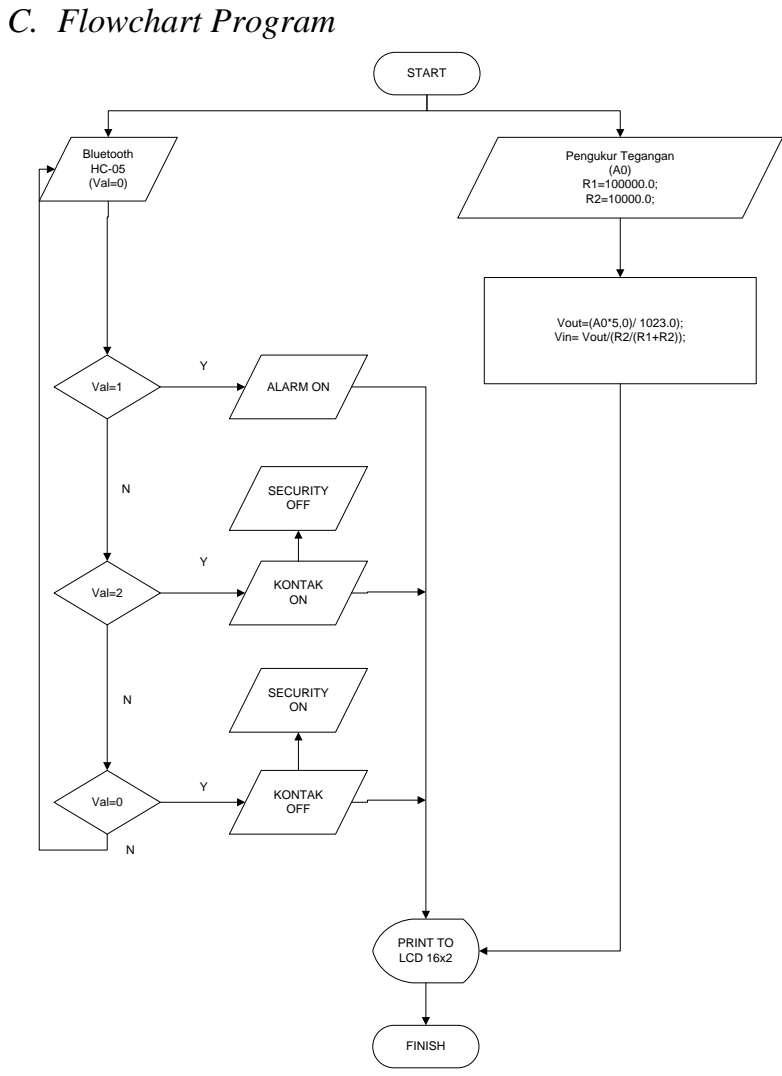

Gbr. 3 Flowchart

\section{Hasil Percobaan}

Berikut adalah penjelasan dari proses percobaan yang dilakukan terhadap alat yang penulis buat. Hasil percobaan terbagi menjadi tiga bagian, yaitu:

1) Hasil Input

Pada hasil input alat yang penulis buat, ketika kita sudah menghidupkan bluetooth kemudian membuka aplikasi Arduino RC dan menyandingkan dengan bluetooth HC-05 di smartphone android kemudian masuk ke mode terminal kemudian ketikkan angka 1 maka akan mengirimkannya ke bluetooth HC-05. Dari bluetooth HC-05 akan mengirimkannya ke IC ATmega32p. Begitu juga apabila kita ketikkan "2" atau "0" maka akan terkirim ke bluetooth HC-05 kemudian akan dikirimkan ke IC ATmega328P lalu kemudia akan diproses oleh IC ATmega328P tersebut.

Untuk pegukur tegangan input-an akan masuk melalui port A0 (INPUT ANALOG) yang kemudian akan dikonversi menjadi digital dan kemudian akan diproses oleh main program.

\section{2) Hasil Output}

Pada hasil output dari alat yang penulis buat LCD 16x2 berfungsi dengan baik, LCD 16x2 dapat menampilkan tegangan sesuai dengan kondisi tegangan dari aki atau baterai yang ada pada sepeda motor dan juga dapat menampilkan kondisi sepeda motor apakah dalam keadaan "ON", "OFF", dan juga ketika alarm "ON".

Pada hasil output relay juga berfungsi dengan baik ketika kondisi motor dalam status "ON" maka keamanan pada sepeda motor sepeda motor akan "OFF". Sebaliknya ketika kondisi sepeda motor dalam status "OFF" maka keamanan pada sepeda motor akan "ON". Dan ketika kita menghidupkan alarm yang berfungsi untuk mencari sepeda motor ketika di area parkir maka status alarm "ON" dan klakson sepeda motor akan berbunyi 2 kali yang akan menunjukan dimana posisi sepeda motor.

3) Hasil Keseluruhan Alat

Dari hasil percobaan berulang kali pada alat yang penulis buat akhirnya penulis mendapatkan kinerja alat yang sesuai dengan yang diharapkan. Berikut adalah tabel hasil percobaan keseluruhan alat:

TABEL I

Hasil Keseluruhan Alat

\begin{tabular}{|c|c|c|c|}
\hline Fungsi & Input & Keamanan & LCD 16x2 \\
\hline $\begin{array}{c}\text { Pengukur } \\
\text { Tegangan }\end{array}$ & $\begin{array}{c}\text { Dari } \\
\text { Port } \\
\text { A0 }\end{array}$ & - & $\begin{array}{c}\text { Tegangan } \\
\text { aki (volt) }\end{array}$ \\
\hline $\begin{array}{c}\text { Bluetooth } \\
\text { HC-05 }\end{array}$ & 1 & OFF & I am here \\
\cline { 2 - 4 } & 2 & OFF & $\begin{array}{c}\text { Ready to } \\
\text { use }\end{array}$ \\
\cline { 2 - 4 } & 0 & ON & $\begin{array}{c}\text { Can't be } \\
\text { used }\end{array}$ \\
\hline
\end{tabular}

Untuk penempatan alat ini sendiri dapat diletakan di bagian sepeda motor mana saja sesuai dengan keinginan. Untuk penulis sendiri meletakan alat ini di dekat speedometer supaya mudah untuk melihat status dalam LCD nya.

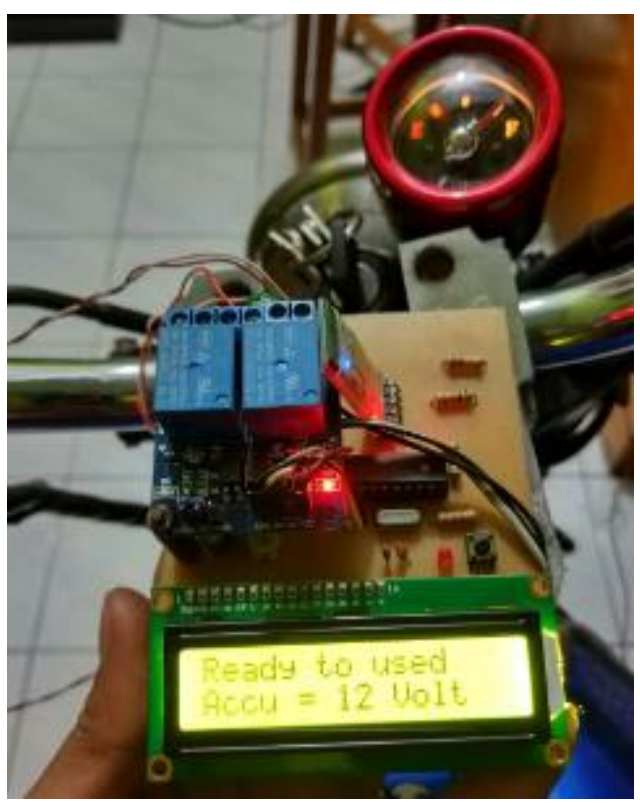

Gbr. 4 Hasil Implementasi 


\section{Kesimpulan}

Dari penelitian yang telah penulis paparkan diatas, penulis mengambil kesimpulan sebagai berikut:

1. Voltage accu/aki dapat terukur dengan baik dan dapat kita lihat di tampilan LCD 16x2 status dari voltage aki tersebut.

2. Ketika kita masukan angka " 1 " maka itu akan berfungsi sebagai pencari keberadaan sepeda motor saat berada di area parkir dengan cara klakson akan berbunyi dan lampu sein sepeda motor akan berkedip, sehingga memudahkan kita untuk menemukan letak sepeda motor.

3. Apabila kita memberi masukan " 2 " melalui smartphone android maka kontak sepeda motor akan ON dan sepeda motor siap untuk digunakan, dan di LCD 16x2 akan menampilkan status "Ready to use". Apabila kita menyalakan kontak sepeda motor tanpa menyalakan melalui smartphone android maka sepeda motor tidak akan hidup.

4. Kemudian apabila kita memberi masukan " 0 " maka kontak sepeda motor akan OF dan sepeda motor tidak dapat digunakan, dan LCD 16x2 akan menampilkan status "Can't be used".

5. Dan untuk mengantisipasi apabila smartphone android kita mati karena kehabisan daya atau karena hal lainnya, kami membuat sebuah saklar alternatif. Yang mana saklar alternatif tersebut berfungsi sebagai kontrol manual untuk menghidupkan dan mematikan kontak sepeda motor. Karena saklar tersebut sangat penting dan tidak boleh diketahui oleh sembarangan orang, maka untuk peletakan saklar tersebut harus bersifat rahasia dan tidak boleh diketahui oleh orang lain, misalnya didalam bagasi ataupun bisa juga di bagian sepeda motor lainnya.

6. Dan dengan adanya alat keamanan tambahan yang penulis buat ini, yang dipasang pada sepeda motor diharapkan dapat mengurangi tingkat pencurian sepeda motor yang saat ini sedang marak terjadi disekitar kita.

\section{Referensi}

[1] Badan Pusat Statistik, "Jumlah Pesawat dan Kendaraan Bermotor Menurut Jenisnya, 1949-2013," Badan Pusat Statistik, 2017. [Online]. Available: https://www.bps.go.id/index.php/linkTabel Statis/1425.

[2] N. N. Nibras, "Ini 11 Jenis Kejahatan Yang Menonjol Selama 2016," Kompas.com, Jakarta, 2017.

[3] M. K. Rijal, "Robot Beroda Pemantau Suhu Dengan Display Pada LCD Berbasis Arduino Mega 2560," 2017.

[4] E. Wiji Setio Budianto, Ramadiani, and A.
H. Kridalaksana, "Prototipe Sistem Kendali Pengaturan Suhu Dan Kelembaban Kandang Ayam Boiler Berbasis Mikrokontroler Atmega 328," Pros. Semin. Nas. Ilmu Komput. dan Teknol. Inf., vol. 2, no. 2, pp. 70-73, 2017.

[5] Y. A. Putra and A. Yuwaldi, "Rancang Bangun Sistem Data Logger Pergerakan Sepeda Motor Berbasis Mikrokontroller ATmega328p," 2015.

[6] S. D. Ermansyah, "Implementasi System Voice Recognition Dan Rotary Encoder Pada Mobile Robot Sebagai Sistem Navigasi Dan Perhitungan Posisi Robot," 2016. 